\title{
Small and Medium-Sized Enterprises Financing: A Review of Literature
}

\author{
Abdulaziz M. Abdulsaleh ${ }^{1} \&$ Andrew C. Worthington ${ }^{1}$ \\ ${ }^{1}$ Department of Accounting, Finance and Economics, Griffith Business School, Griffith University, Australia \\ Correspondence: Abdulaziz M. Abdulsaleh, Department of Accounting, Finance and Economics, Griffith \\ Business School, Griffith University, Australia. Tel: 61-41-264-8017. E-mail: a.abdulsaleh@griffith.edu.au
}

Received: April 3, 2013 Accepted: May 6, 2013 Online Published: June 18, 2013

doi:10.5539/ijbm.v8n14p36 URL: http://dx.doi.org/10.5539/ijbm.v8n14p36

\begin{abstract}
There is no doubt that access to finance is of crucial importance for the ongoing and sustainable growth and profitability of small and medium enterprises sector (SMEs) through its role in facilitating the creation of new businesses and nurturing the innovation process as well as promoting the growth and development of existing businesses, which in turn, boost national economic growth. The main motive of this paper is that SMEs significantly differ from large firms in terms of their financial decisions and behaviour. Hence, the purpose of this paper is to review the literature on the various financing sources of SMEs taking into account the effects of both SME characteristics and those of the owner-managers on SME financial behaviour.
\end{abstract}

Keywords: small and medium sized enterprises SMEs, financing

\section{Introduction}

The availability of finance has been highlighted as a major factor in the development, growth and successfulness of SMEs (Ou \& Haynes, 2006; Cook, 2001). Financing methods employed by SMEs vary from initial internal sources, such as owner-manager's personal savings and retained profits (Wu,Song, \& Zeng, 2008) to informal outside sources, including financial assistance from family and friends (Abouzeedan, 2003), trade credit, venture capital and angel financiers (He \& baker, 2007), and thence to formal external sources represented by financial intermediaries such as banks, financial institutions and securities markets (Chittenden, Hall, \& Hutchinson, 1996).

According to the financial growth cycle paradigm proposed by Berger and Udell (1998) financial needs and the financing options available for SMEs change throughout the various phases of a firm's lifecycle. In other words, at different stages of the firm's growth cycle, different financing strategies are required. In general, because of the unique features that characterise SMEs during the start-up phase, such as informational opacity (Berger \& Udell,1998), a lack of trading history (Cassar, 2004) and the high risk of failure (Huyghebaert \& Van de Gucht, 2007), SMEs in this stage depend heavily on insider funding sources.

As SMEs advance through their business lifecycle, they begin to gradually adjust their capital structure (La Rocca, La Rocca, \& Cariola, 2011). During subsequent growth stages as SMEs mature, they start to establish a track record in addition to the ability to provide collateral. This serves to improve the creditworthiness of the firm and thereby attracts the attention of investors willingly inject money into the business. As a consequence, firms begin substituting internal with external financing sources, including venture capitalists, trade credit and bank loans to name a few. In the more advanced stages of their growth cycle, when SMEs become more informationally transparent, they may develop access to securitised debt and publicly listed equity markets (Berger\& Udell, 1998).

A number of empirical studies, including Kimhi (1997) and Barton and Gordon (1987), use the lifecycle model as their chosen approach to understand the financial behaviour of SMEs. In line with these studies, La Rocca et al. (2011) found that the financial behaviour of SMEs can be, to a large extent, attributed to the lifecycle pattern which was found consistent over time and quite similar across different industries and institutional contexts. In addition, in their study of small businesses financing using a sample of 60 SMEs across three cities in China, Wu et al. (2008) found evidence supporting the business life cycle model.

However, other studies critique the growth life cycle model claiming that it does not offer a complete picture of 
SME financial decisions and behaviour. For example, Berger and Udell (1998) themselves concede that the lifecycle paradigm is not applicable to all SMEs operating in different industries implying that firm size, age and information availability -which are intended to constitute the backbone of this particular paradigm- are not perfectly correlated. Gregory, Rutherford, Oswald and Gardine (2005) partially agreed with the model stating that SMEs financing cannot be standardized. Moreover, according to their results and contrary to the growth lifecycle model suggestion that the financial needs and options of SMEs lie on some size/age/information continuum, only firm size was found to be a significant predictor (in some, but not all cases) of capital structure decisions in SMEs.

The SME financing pattern explained by Berger and Udell (1998) contrasts with the hypothesis given under pecking order theory. The pecking order theory developed by Myers (1984) suggests that the capital structure decisions of a firm are a function of the firm's age. As postulated by this theory, internal sources of funding are prioritised while the use of external sources is delayed until the internal sources are exhausted. As such, when seeking funds, a firm prefers internal equity to external debt, short-term debt to long-term debt, and external debt to external equity. Therefore, the order of preference for the financing sources for a firm should follows internal equity, issuing debt, and then issuing equity (Cassar \& Holmes, 2003).

Consistent with pecking order theory and contrary to the lifecycle model, Gregory et al. (2005) argue that older firms should be less reliant on external financing sources than younger firms. They attribute this to the fact that because older firms have more opportunities to accumulate retained earnings than younger firms, more internal funds are available to finance their operations. Work by Sanchez-Vidal and Martín-Ugedo (2005) on the Spanish SMEs also supports the pecking order theory.

The pecking order theory was tested by Helwege and Liang (1996) who examined the financial decisions of a sample of young small businesses between 1984 and 1992. According to their empirical results, financing patterns followed by the firms in their sample did not match the pattern suggested by the pecking order theory. They further found, contrary to what the theory suggests, no evidence of significant relationship between the raising of finance externally and a deficit in internal sources. Additionally, while theory predicts that equity issuance should be avoided by firms with greater information asymmetry their results show that asymmetric information variables have no power to affect such decisions.

Despite the effort that has been made to theorize SME financial behaviour resulting in the different financing patterns followed by SMEs, it seems that different theories suggest different approaches. However, there is general agreement on the effect of SME characteristics and those of entrepreneurs on the financing methods chosen and employed by SMEs. In the following section, the effects of the characteristics are briefly discussed before going beyond and reviewing the literature on SMEs financing sources.

\section{SMEs Characteristics}

In general, the characteristics of SMEs affect their financial decisions and behaviour and ultimately the firm's performance and growth. In this context, the literature has identified several characteristics peculiarly related to the SMEs sector as factors influencing the financial behaviour of firms in this sector. These include firm size and age, ownership type and legal form, geographical location, industry sector and asset structure (reflecting the ability to provide collateral).

\subsection{Size and Age}

Even though there is no consensus amongst researchers about the criteria that should be employed to measure the size of the firm (typically total assets, sales or the number of employees), the notion that firm size has an effect on SME's activities and its potential to expand appears to receive general agreement. A firm's size is usually coupled with its age as they tend to have similar influence on the firm's life cycle. This influence can be strongly observed in the decision making process in the firm about whether one particular sort or another of finance should be chosen and utilized (Cassar, 2004). Studying firms financing and capital structure using a sample consisted of 292 Australian firms, Cassar (2004) concluded that the "larger" small firms are, the more they rely on long-term debt and external financing, including bank loans. This is consistent with Storey (1994) who found that in the case of SMEs, the owner-manager's personal savings are more important as a source of funds during the start-up stage than outside finance such as loans and overdrafts from banks. From another angle, the extent to which firm size can impact the availability of finance to the firm was measured by Petersen and Rajan (1994). They argued that as firms grow, they develop a greater ability to enlarge the circle of banks from which they can borrow. They then provided evidence that firms dealing with multiple banks and credit institutions are nearly twice as large as those with only one bank. 
As younger firms are usually characterised by informational opacity (Berger \& Udell, 1998) as a consequence of not having an established track record, this may lead to the reluctance of banks and other financial institutions to lend to these firms. According to Klapper, Sarria-Allende and Sulla (2002), younger enterprises (those established less than four years), are more reliant on informal financing and far less on bank financing. This is supported by Quartey (2003) who concluded the significant positive effect of firm age on the ability to access external finance. In addition, in their investigation of the impact of firm and entrepreneurial characteristics on SME access to debt finance in South Africa, Fatoki and Asah (2011) observed that SMEs established more than five years have a far better chance to be successful in their credit applications compared with SMEs established for less than five years.

\subsection{Ownership Type and Legal Form}

There is a positive relation between SME leverage and the type of organisational structure (Coleman \& Cohn, 2000). This is in line with Abor (2008) who identified the form of business as one of the factors explaining the capital structure decisions of Ghanaian SMEs. In addition, ownership structure and the type of firm were found to have a significant impact on the use of bootstrap financing. Van Auken and Neeley (1996, p. 247) state that:

"Owners launching firms organised as either a sole proprietorship or non-construction/manufacturing firms should be prepared to use more bootstrap financing than other firms. Owners of these types of firms should be prepared to develop a financial plan that incorporates the use of greater variety of financing alternatives than owners of firms organised other than a sole proprietorship non-construction/manufacturing firms. As such, a sole proprietorship of non-construction/manufacturing firms should recognize the potential for the associated greater number of constraints and difficulties in raising start-up capital".

From the financier's point of view, as SMEs are by nature characterised by concentrated ownership and control in the same owner-manager, which leads to maximizing the information asymmetry problem, the reluctance in lending to SMEs and the extensive use of collateral are understandable and justified (Hutchinson, 1999). Consistent with this, Petty and Bygrave (1993) inferred that the lack of separation between the firm and the owner affect the financing preferences of the firm.

In terms of legal form, Cassar (2004) notes that incorporation may be perceived by banks and other finance suppliers as an encouraging sign of the firm's formality and creditability. Consequently, incorporated firms appear to be in a very favoured position in receiving external funding in comparison with unincorporated firms. Other studies (Storey, 1994) concluded that limited private companies are more likely to be reliant on bank financing.

\subsection{Location}

The geographical area where a firm is located in the proximity of banks is also believed to have an influence on the firm's ability to gain external finance. For example, SMEs located outside major cities face greater difficulties in acquiring external finance, especially long-term debt, compared with their counterparts operating in cities (Abor, 2008). In the same regard, Fatoki and Asah (2011) added that the geographical location of SMEs close to their banks advantages them in that they can better cement relationship lending with those banks. As a result, SMEs are better able to access bank loans using no more than soft qualitative information.

A study conducted by Okpara and Wynn (2007) reported poor location results in inaccessible businesses to both customers and suppliers as one of the reasons for SME failure in Nigeria. Additionally, another study by Reddy (2007) examined the challenges and obstacles encountered by SMEs in Fiji. They found that in spite of the relatively high cost of rentals, SME owners preferred to move their firms' activities to urban areas to escape the negative impact of the local environment features of rural areas on raising external finance, including poor local transportation and communications infrastructure, and consequently on the performance and growth of their firms which made their survival more difficult where such a climate exists.

\subsection{Industry Sector}

A number of studies evidenced that factors related to the industry sector in which a firm operates also explain capital structure and financial decisions (Mackay \& Phillips, 2005; Michaelas, Chittenden \& Poutziouris, 1999). Firms in the services sector, for example, can differ from those operating in manufacturing or construction in terms of financial needs and choices. Michaelas et al. (1999) empirically analysed the different capital structure determinants across time and industries utilizing a sample of 3,500 randomly selected SMEs across ten industries in the UK. They summarised that the impact of industry on short-term and long-term debt varies greatly across industries.

The effect of industry classification on the capital structure of Ghanaian SMEs was examined by Abor (2007). 
The results of the study revealed some differences in the funding preferences of the Ghanaian SMEs across industries. SMEs in the agriculture sector and medical industries rely more on long-term and short-term debt than their counterparts in manufacturing. Abor (2007) further concluded that short-term credit is more used in wholesale and retail trade sectors compared with manufacturing SMEs, whereas construction, hotel and hospitality, and mining industries appear to depend more on long-term finance and less on short-term debt.

\subsection{Assets Structure}

As the provision of collateral plays an indispensable role in easing SME access to debt finance. SMEs that have more fixed assets tend to utilise higher financial leverage (Bradley, Jarrell, \& Kim, 1984). The reason for this is that these firms can borrow at lower interest rates as their loans are secured with these assets serving as collateral. This explains why Coco (2000) describes collateral as the lender's second line of defence.

In their investigation of the role of collateral and personal guarantees using a unique data set from Japan's SME loan market, Ono and Uesugi (2009) found that a positive relationship between the use of collateral and the strength of the borrower-lender lending relationship results in easier SME access to external sources of finance. A similar conclusion was reached by Odit and Gobardhun (2011) when examining the factors determining the use of financial leverage by SMEs in Mauritius. They concluded that access to debt finance is affected by the positive association between the debt ratio and the asset structure. Furthermore, they revealed that SMEs with a lower portion of tangible assets in their total assets are more likely to encounter difficulties in applying for outside finance because of the inability to provide the collateral required.

\section{Owner-Manager Characteristics}

The personal characteristics of the owner-manager also make a difference to the firm's ability and likelihood of accessing external finance (Irwin \& Scott, 2010; Cassar, 2004). The reason is that the owner-manager in SME has the dominant position in the firm in their role as the primary decision maker. For example, Berggren, Olofsson and Silver (2000) reasoned that most owner-managers in SMEs do not prefer to finance firm operations using external finance, particularly as it entails changes in ownership structure whereby such financing may lead to control aversion. In the same vein, it has been shown that SME owner-managers themselves exert a noticeable influence on their firms' financing decisions and subsequently performance and growth (Vos, Yeh, Carter, \& Tagg, 2007; Coleman, 2007).

\subsection{Owner-Manager Gender}

Female and male entrepreneurs generally differ in the way they finance their businesses (Verhuel \& Thurik, 2001; Carter \& Rosa, 1998). As reported in the enterprise literature, the issue of differences in financing sources related to gender among SMEs is more highlighted during the introductory (start-up) stage. For example, Verhuel and Thurik (2001) found that although men and women do not significantly differ with regard to the type of capital, women SMEs owners appear to have a smaller amount of start-up capital. In addition, women-owned SMEs begin in business with less than half of capital amount used by men and face more credibility issues when dealing with bankers (Badulescu, 2011). In parallel, Mijid (2009) found higher loan denial rates and lower loan application rates among female entrepreneurs. Coleman (2007) also provided evidence of credit discrimination against female entrepreneurs as they were more frequently charged higher interest rates and asked to pledge additional collateral in order for loans to be granted.

Explanations given in the literature for differences between men and women entrepreneurs with respect to access to finance can be categorised into discrimination, abilities and preferences, and competition (see Harrison \& Mason, 2007). Moreover, Verhuel and Thurik (2001) divided the impact of gender on SMEs capital into direct and indirect effect. The former "gender effect" refers to the fact that while male and female entrepreneurs may share characteristics but they are different in the way in which they finance their firms. However, the latter "female profile" can be more attributed to differences related to business type, management and experience.

\subsection{Owner-Manager Age}

It is often found that the personal financing preferences of entrepreneurs appear to change according to age. According to Romano, Tanewski and Smyrnios (2001), the effect of the owner-manager's age on the financial behaviour of SMEs can be noted in that unlike younger entrepreneurs, older entrepreneurs are less likely to invest additional finance into their firms. This finding is in line with that of Van der wijst (1989) who suggests that older SME owner-mangers are more reluctant when it comes to accepting external ownership in the firm. Further, Vos et al., (2007) examined SME financial behaviour utilizing two data sets from the UK and the US consisting of 15750 and 3239 SMEs, respectively. The results show that younger owner-managers tend to use more bank overdrafts and loans, credit cards, own savings, and family sources than older owners who appear to 
be more dependent on retained profits.

Clarifying the connection between the financial growth cycle of SMEs and the owner-manager's life cycle, Briozzo and Vigier (2009, p. 37) state that;

"As the firm and its owner grow older, information asymmetries decrease, granting easier access to debt (a supply-side effect), while the owner's risk aversion and personal costs of bankruptcy increase with age, and thus he or she desires to use less leverage (demand side effect)".

\subsection{Owner-Manager's Education and Experience}

Employed by institutional financiers as a proxy for human capital, the educational background of the SME owner-manager is often positively related to the firm's usage of leverage (Coleman, 2007). A study by Bates (1990) examining the impact of owner-manager's personal characteristics on SME longevity across a wide sample of SMEs owned-managed by men across the US between 1976 and 1986 concluded that owner-managers who had higher levels of education were more likely to retain their firms operating throughout the period of study. He further emphasised that the level of education of entrepreneurs is a major determinant of banking loans amounts offered to SMEs. As for the demand side, Storey (1994) asserts that higher levels of education provide entrepreneurs with greater confidence in dealing with bankers and other funders when applying for loans.

Turning to experience, as measured by the number of years in an industry, Cole (1998) found that experience also enhances the availability of credit. In fact, Nofsinger and Wang (2011) hypothesised that the experience of the entrepreneur is one factor that explains the difference in external financing levels available to SMEs. The findings of the study proved this hypothesis. They further explained that prior experience in the industry positively correlates with the share of external financing in the firm and added that the cumulative experience of the owner-manager plays a crucial role in overcoming some of the problems that hinder SME access to external finance, including information asymmetry and moral hazard. From the lender's perspective, as experienced entrepreneurs are believed to be better performers than less experienced entrepreneurs, it is then rational to factor experience into the process of evaluating the creditworthiness of SMEs (Gompers, Kovner, Lerner, \& Scharfstein, 2010).

\section{Sources of SMEs Finance}

\subsection{Equity Financing}

Due to moral hazard and problems with information opacity typically being more severe during the initial stages of SME development, internal equity financing, as best represented by owner-manager personal savings, is a critical source of funding for SMEs in these early stages (seed financing and start-up). Subsequently, in later stages, in order to develop and grow SMEs tend to reduce their dependence on these sources and start seeking alternative channels for raising capital. Internally generated profits and venture capital exemplify just two of the other equity options SMEs seek to expand as they grow.

In general, “...equity capital is that capital invested in the firm without a specific repayment date, where the supplier of the equity capital is effectively investing in the business" (Ou \& Haynes, 2006, p. 156). Equity capital can be raised either internally or externally. Internal equity is funds obtained from the current owner-manager(s), family, and friends or from the retained earnings within the firm. External equity, however, is capital acquired from external channels other than the existing partners and their relatives.

As mentioned above, equity financing is preferred over debt as a mode of financing for new and young SMEs as they undergo a typical cash shortage and are generally unable to secure loans with collateral during the founding phase. The advantages of equity financing in this regard are twofold (Ou \& Haynes, 2006). First, unlike debt, equity offers long-term financing with minimum cash outflow in the form of interest. Second, equity capital helps enhance the new/young firm's creditability by indicating that the firm has the approval of sophisticated financial professionals.

Ou and Haynes (2006) determined two situations when SMEs pursue financing from equity capital sources in order to meet expansion needs. The first case is when SMEs face financial distress coupled with a lack of alternative sources of finance. The second case is when cash outflows exceed the cash inflows generated from regular sources. Ou and Haynes (2006) attributed this attitude adapted by SMEs in these two particular cases to the reluctance of regular lenders to lend to the firm because of uncertainty about the firm's future growth opportunities. As a result, these firms are usually classified as high risk. Inconsistent with this, in their investigation of the determinants of financing mode chosen by young innovative SMEs in Germany, Schäfer,Werwatz and Zimmermann(2004) found that risky SMEs are more likely to receive equity financing. 
Other arguments suggest that some SMEs owner-managers may choose not to use equity as a source of financing in order to avoid any undesirable changes in the ownership of their firm (Reid, 1996). Other entrepreneurs, nevertheless, may choose to source funding from external equity in order to share the risk with less risk-averse investors. However, the valid judgement of the importance of the external equity for SMEs should be based on the eventual success of firms that receives it, not on the quantity that the firm utilises (Berger \& Udell, 1998).

\subsubsection{Venture Capital}

Venture capitalists are financial intermediaries. Venture capital is that form of financing in which funds are raised from investors and redeployed by investing in high-risk informationally opaque firms which for the most part are young or start-up firms (Potter \& Porto, 2007). Further, venture capitalists decide the timing and type of investment in addition to their role in monitoring, screening and contracting (Gorman \& Sahlman, 1989). Moreover, by performing these functions, venture capitalists virtually participate in strategic planning and decision making in the firm. The venture capital market includes a variety of organisations, including public corporations, small business investment corporations and private limited partnerships.

Compared to other more conventional financing sources, venture capital displays some particular characteristics. To start with, investments employing venture capital often involve high levels of asymmetry information and uncertainty as well as higher intangible assets (Gompers, 1995). In addition, Hellmann (1998) explained that the situation in which a company has a sufficiently large incentive for active monitoring takes place only when the venture capitalist has a concentrated stake invested in that company. He added, monitoring in such cases may include spending more time in the company and regular meetings with the managers. Finally, venture capitalists can provide the firm with strategic access to new suppliers and clients as well as strategic partners (Bygrave \& Timmons, 1992).

As discussed, venture capital investment is uniformly associated with high risk and uncertainty. For example, when providing external finance to firms, venture capitalists encounter a significant adverse selection problem and moral hazard (Smolarski \& Kut, 2011). Another problem that may arise is the agency problem (Berger \& Udell, 1998). This occurs in the relationship between the venture capitalist and the entrepreneur when the latter lacks sufficient information or skills to make optimal production decisions. This problem might also be combined as information about the project is imperfect and revealed over time (Bergemann \& Hege, 1998). In order to alleviate these problems and reduce uncertainty, particular mechanisms can be implemented. In this context, Gompers (1995) emphasised three control strategies. These strategies are: (i) the use of convertible securities, (ii) the syndication of investment, and (iii) the staging of capital infusions.

According to Cumming (2006), most venture capital transactions include convertible securities. Bascha and Walz (2001) asserted that unlike traditional debt and/or equity instruments, convertible securities have the ability to mitigate the agency problem effects by leaving the owner-manager with some control during the investment period. In addition, as the price of conversion is a function of performance, the venture capitalist has a better chance to recover the investment if the venture is not successful. Other studies show other motivations for employing convertible debt, with examples including reducing the risk-shifting incentives of the entrepreneur (Green, 1984), resolving problems arising with debt financing and gaining indirect equity financing when issuing traditional equity is unattractive (Stien, 1992).

Syndication is a common form of venture capital risk alleviation and refers to two or more venture capitalists sharing in a single financing round. The syndication mechanism is used in order to decrease problems associated with adverse selection through the participation of a co-investor sharing the investment risk (Smolarski \& Kut, 2011). A study by Cumming (2006) reached a broadly similar conclusion stating that venture capital syndication significantly mitigates adverse selection problems. Additionally, Lerner (1994) suggested that adverse selection problem can be efficiently mitigated in the presence of high information asymmetry in venture capital financing by implementing the syndication strategy. It was also found that syndication reduces the entrepreneur's opportunistic behaviour (Wright \& Lockett, 2003).

Another main characteristic of venture capital is staged financing. As the term suggests, venture capital staging refers to that mode of financing in which venture capitalists invest in stages in order to maintain the project under control (Organization for Economic Co-operation and Development [OECD], 2004). Gompers (1995) provided evidence indicating that staged investment enables venture capitalist to gather more information allowing him/her to monitor the firm prior to refinancing decisions to be made. As such, the venture capitalist has the option of abandoning the project if and when any unattractive information regarding the investment emerges. Wang and Zhou's (2004) results showed that the staging financing plays a crucial role in controlling 
moral hazard. Therefore, it is an effective mechanism in controlling agency problems.

Not only do venture capitalists provide an alternative source of funding for SMEs, they also help resolving many informational problems plaguing SMEs. Hence, by helping increasing the financial flexibility of SMEs, they offer them the chance of sourcing finance from other financial channels, such as banks and insurance companies. However, the supply of venture capital appears to be relatively inflexible, at least in the short-term, as it requires years of experience to develop the necessary skills (Kortum \& Lerner, 2000).

\subsubsection{Business Angels}

Unlike other external sources of financing, business angel finance is not intermediated. It is instead an informal market for direct finance (Berger \& Udell, 1998). Angels are highly-selective wealthy individuals with long business experience who invest directly in high growth SMEs with which they have had no previous relationship (Madill, Haines, \& Riding, 2005). This form of investment is usually based on an equity contract, typically common stock. Though angels by definition are individuals, they sometimes coordinate their investment in small investment groups.

According to Harrison and Mason (1992), there are three features that make angel financing an appropriate option for SMEs. First, angels are more active in the early stages of enterprises (seed and start-up) closing the so-called 'equity gap' by forming a 'bridge' between internal financing sources and outside investors. Second, by having lower rates of rejection and being a more patient form of capital with longer exit horizons, angel financiers tend to be more obliging to the needs of SME owner-managers. For example, German entrepreneurs have ranked business angels as the most desirable funding providers (Brettel, 2003). Finally, unlike venture capitalists, angel investors prefer to invest in their local economies where the majority of SMEs operate.

Angel investors are a crucial source of financing for many SMEs, especially start-ups. According to Morrissette (2007), the amount of capital that angels provide is estimated to be eleven times that provided by venture capitalists. Data collected by Shane (2012) from different surveys conducted between 2001 and 2003 showed that between 140000 and more than 260000 angels injected investments between $\$ 12.7$ and $\$ 36$ billion into between 50000 to 57000 ventures each year. In Germany, for example, a study by Stedler and Peters (2003) estimated the total capital assets for each business angel in the country at $€ 2.5$ million to $€ 5$ million distributed across a portfolio of between 1 and 5 firms, all start-ups.

The extent to which angels are involved in the firms in which they invest is debatable. Barry (1994) claimed that angels are not active investors. Yet, other empirical research show opposing results (e.g. Harding \& Cowling, 2006; Landström, 1993). In terms of benefits, Mason and Harrison (1996) questioned a sample of 20 dyads regarding the role played by business angels apart from their financial stake. The respondents reported that nonfinancial contributions made by angels included assistance with management functions, finance and accounting functions, strategic advice, financial advice, general administration, networking and marketing. Further, $50 \%$ of the entrepreneurs rated these angel contributions as either helpful or extremely helpful.

Worldwide, and based on quantitative analysis, angel financing dominates venture capital financing in terms of both the number of firms utilizing it and the financial value of investment (Fairchild, 2011). However, as a source of financing, business angels have two main limitations (Wall, 2007). First, few angels are prepared to inject additional money into a firm to enable it to grow and be a real competitor in its market. Second, most angel investors do not have neither the skills nor the interest in investing in a firm after it has access to other external sources of finance, including public equity markets.

\subsection{Debt Financing}

It is well known that capital structure decisions, in SMEs as in large firms, relate to the use of either equity or debt or both. However, Berger and Udell (1998) believe that in the case of SMEs, this is partly incorrect because information opacity is more severe in SMEs. Issuing additional equity to satisfy the firm's financial needs would then lead to a dilution in ownership and control. Therefore, in order to keep full ownership and control of their businesses, SMEs owner-managers may prefer to seek debt financing rather than external equity.

Three significant differences between debt financing for SMEs and that of large firms have been identified in the literature (Wu et al., 2008). First, unlike managers of large firms who usually have the choice of broader range of debt financing resources, SMEs tend to be more attached to commercial lenders, especially institutional lenders, as a source of short-term debt financing that can be renewed for long-term debt. Second, as information asymmetry problems are more acute in SMEs than in large firms, long-term lending relationships are important for SMEs in order to deal with the resultant agency problems along with the other three conventional mechanisms; signalling, monitoring and bonding (the provision of guarantee or collateral). Third, in 
concentrated owner-managed SMEs, and contrary to what the agency theory suggests, it is not clear whether debt can lower the agency costs that result from information asymmetry arising due to different motives of owners and managers.

Choosing between short and long-term debt is important when making capital structure decisions. Short-term debt decisions are influenced by the benefits and disadvantages associated with its use (García-Teruel \& Martínez-Solano, 2007). Jun and Jen (2003) summarised short-term debt advantages as a funding source. These advantages include (i) zero interest rate in some short-term debt cases such as in the case of trade credit; (ii) in comparison to long-term loans, short-term debt has generally lower nominal interest rates; (iii) short-term debt is easy to adapt according to the firm's financial needs; and (iv) lower costs of flotation than those of long-term loans. In addition, from the lender's point of view, short-term debt is an efficient way to deal with asymmetry information problems as firms have to repay the debt and any associated charges over a shorter constant period (Myers, 1977). However, the main drawback of short-term debt is the higher level of risk. Hence, financially weak firms would prefer long-term debt as they perceive short-term debt benefits do not abolish its additional risks (García-Teruel \& Martínez-Solano, 2007).

\subsubsection{Trade Credit}

One of the most important sources of external financing for SMEs is trade credit. For instance, Berger and Udell (2006) estimated that one-third of the total debt of SMEs in the US in 1998 was represented by trade credit. According to García-Teruel \& Martínez-Solano (2010) trade credit is a delay in the payment for goods or services after they have been delivered or provided as a result of an agreement between the supplier and the firm. Therefore, for the firm this is a source of financing appears in the balance sheet under current liabilities, whereas for the supplier it is an investment in accounts receivable.

The rationale behind the widespread use of trade credit among SMEs has been argued in the literature. Ellihausen and Wolken (1993) attributed this attitude to both transaction motive and financing motive. The transaction motive suggests the better ability for both parties (the seller and the buyer) to predict their cash needs in the short-term. As such, cash management transaction costs can be economized. The financing motive is that SMEs resort to trade credit when alternative sources of finance are unavailable or more expensive. In addition, (Fatoki \& Odeyemi, 2010) argued that trade credit financing is preferred by new and young SMEs when the risk of default is high during the early years of operations. Moreover, in relation to financial motives, firms with easier access to credit market can act as a financial intermediaries and offer funding for firms that face difficulties in accessing external financing (Demirgüç-Kunt \& Maksimovic, 2001).

The role of trade credit as a source of raising financing for SMEs is even more important in countries with less developed banking and financial systems where asymmetric information problems are more pronounced. In China, for example, Allen, Qian and Qian (2005) attributed the accelerating growing of the country's economy, rather than formal external finance, to alternative sources, foremost of which is trade credit. Supporting this, Yano and Shiraishi (2012) investigated the efficiency of trade credit as an alternative channel for funding rural SMEs in China using firm-level microdata over the period from 1999 to 2005. They concluded that offering more trade credit to SMEs can assist these firms in their post-entry survival, thereby strengthening their opportunity to thrive.

Another example comes from Russia where the financial and banking system is also typically considered less developed. Employing data from a survey of 352 Russian firms in 1995, Cook (1999) emphasized the unique positive role of nonfinancial firms, namely trade credit suppliers, acting as financial intermediaries in addressing problems with information asymmetry. Cook (1999) explained two ways through which trade credit can surmount capital market imperfections. First, as trade credit suppliers have more information on their partners' businesses, trade credit can mitigate the problem of information asymmetry enabling them evaluate and control the credit risk of their buyers. Second, by using trade credit SMEs can demonstrate their creditworthiness to banks, consequently, banks will be more willing to lend to them on the basis of this signal.

Some researchers (e.g. Wilson \& Summers, 2002) argue that trade credit can be a costly financing source for SMEs if the buyer delays the payment beyond the specified date in the agreement. Nevertheless, Berger and Udell (2006) believe that in spite of some drawbacks, trade credit remains a crucial financing source for most SMEs, especially the young. They further explained that trade credit has the ability to provide the desired cushion during credit crunches, contractions of monetary policy or other shocks that may make other funding suppliers unwilling to provide financing to SMEs. 


\subsubsection{Nonbank Financial Institution Debt}

As finance institutions tend to differ from banks in their lending policies possibly in part because of regulatory differences (Berger \& Udell, 1998) and following Ayyagari, Demirgüç-Kunt and Maksimovic (2010) who separate bank finance from other nonbank financial institutions funding, the focus in this section is on nonbank financial institutions as the role of banks will be discussed in the later section.

In spite of the important and unique role played by nonbank financial institutions, including credit unions, pension funds, finance houses, investment trust companies, finance companies and insurance companies, in meeting the financial needs of SMEs, the market for nonbank debt has been largely ignored in the finance literature (Arena, 2011). Nonetheless, some researchers have attempted to investigate this role. For example, Atieno (2001) investigated and assessed the role of such institutions in facilitating the access to credit by SMEs in rural Kenya. He attributed the dominance position of these institutions as funding providers to SMEs to the fact that their procedures for loan applications are shorter than those of commercial banks. He adds another advantage makes this financing source favourable to SMEs which is longer loan maturity periods.

Nonbank debt offers a channel for SMEs to raise funding in both developing and developed nations. In Zimbabwe, for example, loans granted by nonbank financial institutions account for nearly 30 percent of total debt, and were ranked second in order of importance by domestic SMEs (Aryeetey, 1998). A more recent study conducted by the Federation of Small Businesses found that 15,000 financial institutions in the US competed to lend to SMEs, of which half were nonbank lenders in the form of credit unions (Goff \& Nasiripour, 2012). Still in the US, an earlier study by Denis and Mihov (2003) using a sample of 1,560 new debt issuers firms during 1995-96 showed that of total amount of debt of $\$ 350$ billion raised by the firms in the sample, nonbank debt was responsible for almost $\$ 40$ billion.

Johnson (1997) explained that while banks prefer short-term debt as their liabilities are also short term, nonbank financial institutions such as insurance companies are generally in favour of long-term loans as they have long-term liabilities. However, Johnson (1997) believes that nonbank financial institutions can act as a financial intermediate between banks and public debt.

In general, the main advantage that encourages SMEs to use more debt than other external sources of finance in their capital structure is the tax shield benefit. In addition, when seeking external funding, SME owner-managers tend to limit the use of equity in order to meet control aversion and maintain control of their firms (Hutchinson, 1995). However, Abor (2008) found that SMEs with many shareholders (group-owned SMEs) may choose to utilize low debt levels to avoid bankruptcy and the agency costs accompanied with debt financing.

\subsection{Bank Finance for SMEs}

A large body of the existing literature has documented that banks are the main external capital provider for SMEs sector in both developed and developing countries (Vera \& Onji, 2010; Ono \& Uesugi, 2009; Zhou, 2009; Wu et al., 2008; Carey \& Flynn, 2005; Cole \& Wolken 1995). De Bettignies and Brander (2007) assume that bank loans are available for SMEs on competitive and fair basis.

In order to optimize their capital structure, Moro, Lucas, Grimm, \& Grassi (2010) suggested that SMEs should only focus on bank financing. Keasey and McGuinness (1990) argued that in spite of the fact that bank financing is more expensive in comparison to other sources of finance, it generates a higher rate of return for SMEs. They further conclude that bank finance can help SMEs accomplish better performance levels than other financing sources can do. The explanation given by them is that SMEs employ the funds more efficiently when they are monitored by, and answerable to banks.

From the perspective of banks, SMEs segment represents a strategic profitable part of bank business. In this regard, de la Torre, Martinez and Schmukler (2009) described the engagement between SMEs and banks as integral. They explained that banks do not only provide the necessary capital for entrepreneurs to establish new SMEs or expand the existing ones they also offer a variety of services and financial products. The findings of Beck, Demirgüç-Kunt and Martinez (2008) have highlighted a number of factors perceived by banks as drivers to finance SMEs. The most important factor is the great potential of profitability associated with the involvement with SMEs as banks perceive this sector as unsaturated with good prospects. Another factor is the possibility to seek SMEs clients through their relations with their large clients. Banks involvement with SMEs is also driven by the intense competition in other sectors such as the large business and retail customers.

The empirical literature on bank financing to SMEs emphasises some mechanisms, techniques and models developed and adopted by banks to lend to SMEs such as relationship lending (e.g., Petersen \& Rajan, 1994), factoring (e.g., Soufani, 2002) and scoring (e.g., Frame, Srinivasan, \&Woosley,2001) just to mention some. 
Relationship lending is a powerful mechanism used to reduce problems related to opaqueness in firms especially SMEs. Under relationship lending, "soft" information is gathered by a financial institution (usually small local bank) through continuous contact with the firm (usually SME) in the provision of financial services (Berger \& Udell, 1998, p. 645). The information will be then used to evaluate the creditworthiness of the entrepreneur as a part of the loan process to ensure that the potential loan will be repaid. The strength of the relationship lending, measured by its duration or the breadth of the relationship, was found positively correlated to the availability of funds for SMEs (Petersen \& Rajan, 1994). In addition to this, the literature reports other benefits including; lower cost of credit, protection against credit crunches and the provision of implicit interest rate or credit risk insurance (Berger \& Udell, 1998). Other study suggested that in order to increase credit supply for SMEs trust-based relationship lending is more effective than the establishment of longer or more concentrated bank-borrower relationship (Hernández-Cánovas \& Martínez-Solano, 2010).

Based mainly on "hard" quantitative information, credit scoring is a lending technology used by financial institutions especially banks to evaluate informationally opaque loans applicants. Unlike the information in relationship lending which need long time to be acquired, the hard data required by credit scoring technology are readily gathered usually from consumer credit bureaus and commercial credit bureaus. It has been evidenced in the literature that credit scoring method increases the credit availability for SMEs. Berger, Frame and Miller (2002) concluded that implementing credit scoring leads to an increase in the supply of credit to SMEs. Additionally, Frame et al. (2001) found that for the banks included in their sample the portfolio share of SMEs increased by $8.4 \%$ as a result of adopting credit scoring technology. Moreover, according to Berger and Frame (2007) this increase can be split into; (1) increasing the quantity of credit extended; (2) increasing lending to relatively opaque, risky borrowers; (3) increasing lending within low-income areas; (4) lending over greater distances; and (5) increasing loan maturity.

Another transactions technology employing hard information to lend to opaque SMEs is factoring. Factoring is a method to raise short-term finance whereby clients' account receivables are purchased by a specialized firm or a bank for a pre-agreed fee plus interest (Soufani, 2002). Consequently, the specialized firm or the bank takes the responsibility to control and manage a debtor portfolio of a firm. In simple words, factoring is the process resulting in exchanging the account receivable of a firm for cash. As SMEs usually lack the sufficient collateral to obtain finance, as such, using accounts receivable as collateral, that is factoring, to raise finance is significantly important decision to increase SMEs' liquidity (Soufani, 2002). It was found that factoring as an alternative source of finance can play a crucial role in alleviating financing gaps faced by SMEs (Soufani, 2002).

\subsection{Government Assistance and Initiatives}

In both developed and developing countries, governments have recognized that the SME sector faces constrained access to external financing which may negatively affect its crucial role in achieving national development goals. As such, many governmental initiatives and programs have been implemented to ensure SMEs have easier access to financing, of which credit guarantee loans, factoring programs and subsidised fees are typical examples.

According to Mensah (2004, p. 3), government official schemes are those introduced by government either alone or with the support of donor agencies to increase the flow of financing to SMEs. It has been argued that such programs and schemes have the capability to ease the access of SMEs to additional credit (Boocock \& Shariff, 2005). However, Riding, Madill and Haines (2007) maintain that government schemes aim at assisting access to finance for SMEs can be effective only under well-specified conditions. In addition, as SMEs are subjected to credit rationing due to their small size and information asymmetry Zecchini and Ventura (2009) suggested that in order to be effective such schemes should aim at lowering the degree of discrimination against SMEs borrowers in terms of lending costs and unmet demand for fund. Moreover, as for SMEs operating in the export sector, Albaum (1983) recommended that it should be taken into account that not all firms are at the same phase of export development, thus a set of programs targeting firms at different stages of export development is essential.

One example of governmental assistance programs in industrialized countries is that of Small Business Financing Program in Canada (Klyuev, 2008). Under this program, the Canadian government may guarantee up to 85 percent of loans less than $\$ C 250000$. During financial year 2005-06, this program enabled SMEs to attain more than 10,000 loans with total value exceeded $\$ \mathrm{C} 1$ billion. Another example is from the UK. Launched in 1981, the Small Firms Loan Guarantee Scheme aims at facilitating SME access to finance by providing guarantees for SMEs loans (OECD, 2000). Over the period 1998-99, approximately 45000 loans to SMEs were guaranteed with a value of $£ 189$ million.

In developing countries, different pictures emerge. In Croatia, a developing and transition economy, the 
government implemented the National SME Loan Scheme jointly with eight local commercial banks in 2000. The program aimed at increasing the supply of financing targeting SMEs and decreasing the cost of borrowing. However, contrary to expectations, the program suffered from a low rate of loan approvals with only $5 \%$ and 29\% of applicants approved in the first two years; 2000 and 2001, respectively (Cziráky, Tišma, \& Pisarović, 2005). This was attributed to the inconsistency in lending criteria employed by the banks involved in the program. To the contrary, another example positively illustrates the role of such programs, is the Kilimanjaro Cooperative Bank Scheme targeting rural SMEs in the region of Kilimanjaro in northern Tanzania. In his evaluation of this program, Satta (2006) concluded that in terms of loan productivity the Kilimanjaro Cooperative Bank Scheme outperformed all other schemes from Asia, Latin and Central America and the Middle East with 500 active borrowers for each credit officer and an efficiency ratio of $30 \%$.

Three major reasons rationalize government intervention on behalf of SMEs in finance markets, namely, credit market failure, price distortions and dynamic externalities (Bechri, Najah \& Nugent, 2001). Nonetheless, government direct intervention to enhance SME access to finance may also lead to undesirable consequences (OECD, 2004). Some indirect mechanisms and policies can help achieving these programs' objectives. The role of tax legislation is a case in point. In addition, it is assumed that in order to be effective SME financing scheme should meet two principal criteria (Mensah, 2004). First, provide SMEs with their financial needs. Second, they should be sustainable.

\subsection{Islamic Finance for SMEs}

As recently as the 1970s, Islamic finance has emerged as a new trend with promising potential in the field of finance. The rapid growth of Islamic finance is not confined to Islamic countries as it also has spread to non-Muslim countries with sizeable Muslim populations, including the US, the UK and Australia.

It is argued in the Islamic financing literature that many of microfinance elements are in accordance with the Islamic finance's broader objectives. Obidullah and Lattif (2008) believe in the possibility of a successful marriage between the two disciplines. They underpin their belief by clarifying some aspects which these two have in common. According to them both Islamic finance and microfinance encourage entrepreneurship as well as risk sharing between the financier and the entrepreneur. Islamic microfinance adds that both disciplines prioritize developmental and social goals by advocating the participation of the poor in the economic activities.

Ibrahim (2003) argued that Islamic financing methods are better suited in satisfying the financial needs of SMEs. The focus in Islamic financing and investment, he explains, is on the transaction itself instead of the partner's creditworthiness. As such, entrepreneurs are granted funding without an obligation on them to provide strict securities or collateral which SMEs often lack. He adds that because profit and loss sharing is pivotal in Islamic finance, any securities or collateral demanded is not against the risk of loss, rather against possible fraud or repayment evasion. The most popular Islamic financing methods are:

\subsubsection{Musharakah}

Musharakah as a mode of Islamic finance can be defined as "form of partnership where two or more persons combine either their capital or labour together, to share the profits, enjoying similar rights and liabilities" (Al-Harran, 1993, p. 47). In this form, the profits are shared according to a pre-determined agreed ratio, however, in the case of loss it will be shared based on capital contribution ratio. Additionally, In Musharakah contract all partners are entitled to have a role in the management of the project.

According to Lewis and Algaoud (2001) Musharakah contract can be either permanent or diminishing contract. In the former contract, which may last to limited or unlimited period depending on the original agreement, annual equal shares of the profit/loss are ensured for both parties based on pre-agreed deal. In the latter, however, capital is not permanent since the financier receives profits on a regular basis diminishing his/her equity. Consequently, this will gradually increase the total capital of the client till he/she becomes the only owner of the project.

Ibrahim's (2003) findings highlighted some advantages of Musharakah contracts. First of all, compared to the rate of return of conventional finance (interest rate), rates of return for the capital provider in Musharakah are large, thus, financially, for the financing institution financing through Musharakah is profitable. Similarly, the rate of return of the partner's capital is slightly higher than his/her share in the total capital even if this share is less than the financier's. This because the inclusion of management effort in Musharakah. Another advantage for the entrepreneur is that since Musharakah does not require strict collateral guarantees so that it does not leave the entrepreneur with a heavy burden of debts or any other obligations. In addition, Musharakah is a suitable technique of financing for both fixed and working capital. 
Nonetheless, under Musharakah contract some ambiguity may exist regarding the title to assets in case of default or dissolution. In order to partially offset the increased risk in such situation, the procedure could be taken is to register the project's assets under the co-ownership concept provided by a partnership or corporation arrangement. Yet, capital providers especially banks may prefer to opt other Islamic financing method such as Murabahah.

\subsubsection{Murabahah}

Among all Islamic financing modes Murabahah is the most distinct and the most popular. Under Murabahah contract the financier (often Islamic bank) purchases or imports certain goods or commodities (assets or raw materials) ordered by the client and then resells them to the entrepreneur after adding a negotiated profit margin (Dhumale \& Sapcanin, 1999). Under this contract the payment is due in installments. It can be inferred that Murabahah transaction entails two contracts. The first contract is that one between the financier (usually the bank) and the supplier of the goods/commodities. The second is between the financier and the client who applied for the goods/commodities. The fundamental principles that characterize Murabahah contract are summarized in (Gait \& Worthington, 2007). First, the goods/commodities must be clearly classified and identified on the base of accepted standards and must be provided by the time of sale. Second, at the time of sale goods/commodities must be completely owned by the financier. Third, the entrepreneur must be informed of the cost price at the sale point. Finally, both the time of goods/commodities delivery and the due date of payment must be clearly specified.

Khan and Ahmed (2001) considered the most important advantage of Murabahah is that since the financier collateralizes the debt beyond the good/commodity itself, as such, the risk of loss becomes much less than the risk of credit transaction in conventional transactions. In addition, Ibrahim (2003) asserted that Murabahah contracts will ensure that the client will have the intended goods/commodities so that avoiding using the money in a different purpose which is usually the case in the conventional loan contracts. Moreover, unlike Musharakah contract and as mentioned earlier, in Murabahah there is no ambiguity concerning title to the assets as they remain owned by the financier till the payment finalized.

\subsubsection{Mudarabah}

Gafoor (2006) described Mudarabah contract as a profit sharing and loss absorbing rather than profit and loss sharing contract. Mudarabah is a contract between two parties; a capital owner and an investment manager, under which profit is distributed in accordance to a ratio that is pre-agreed between the two parties at the time of the contract, whereas, financial loss is borne solely by the capital provider and the manager losses his/her effort and the expected profit. In other words, Mudarabah refers to two parties involve together to establish a project whereby one party (individual or bank) provides the capital needed and plays no further role in the project while the other (entrepreneur) offers his/her skills, experience and effort. Profits are then divided between the two parties on the base of pre-determined ratio. In the case of loss, however, the financier entirely bears the financial loss and the entrepreneur bears the operating losses and receives no reward for his/her effort. One exception that the entrepreneur becomes liable for the amount of capital invested is in the case of negligence and breach of the terms of the contract (Abdulrahman, 2007).

Segrado (2005) has categorized Mudarabah contracts into three categories. First category is demand deposits in which deposits are not restricted, payable on demand and do not share in any profits. Second category is that of mutual investment deposits where these deposits are combined with the bank's money with the aim to participate in mutual investment transactions conducted by the bank. Under such deposits, the percentage of profit is fixed at the end of the financial year of the bank. The third of these categories is special investment deposits under which deposits will be invested in a specific project or investment in accordance with the depositor's request. In this case the depositor will be entitled to receive profits and is liable for the losses, given that the bank is not negligent or in default. At the end of the deposit period, the bank receives its share of profit against its contribution of experience and management, while the depositor receives his/her share of profit as a capital share contributor.

Due to agency issues accompanied with it, Mudarabah has been perceived as a risky product. As entrepreneurs usually do not keep track records or financial statements (Segrado, 2005; Abdulrahman, 2007) it is difficult to determine the actual profit to be shared between the two parties. Additionally, Warde (2000) concluded that Mudarabah contract was often associated with moral hazard and adverse selection. Part of the reason for this is because honesty, transparency and trustworthiness presumably characterize the entrepreneur cannot be guaranteed. As such difficulties are likely to be unavoidable in Mudarabah contracts, Segrado (2005) suggestsed that specific training to overcome these issues is needed, thus, he confirms that Mudaraba mode might be more 
suitable for businesses with a longer profit cycle.

\section{Conclusion}

The increasing importance of economic contributions made by SMEs sector necessitates better understanding of financial behaviour and practices of SMEs. Taking into consideration that the financial behaviour of large firms cannot be applied to SMEs as large firms significantly differ from SMEs, this paper surveys the literature on the various financing sources available for SMEs including Islamic financing methods. In order to attain more in-depth understanding of the financing decisions of SMEs the paper also explores the effects of the characteristics of both SMEs and their owner-managers on the financing methods chosen and employed by SMEs.

\section{References}

Abdulrahman, A. (2007). Islamic Microfinance: A Missing Component in Islamic Banking. Kyoto Bulletin of Islamic Area Studies, 1(2), 38-53. http://dx.doi.org/ 10.1016/j.jfineco.2004.06.010

Abor, J. (2007). Industry Classification and the Capital Structure of Ghanaian SMEs. Studies in Economics and Finance, 24(3), 207-219. http://dx.doi.org/10.1108/10867370710817392

Abor, J. (2008). Determinants of the Capital Structure of Ghanaian firms. African Economic Research Consortium.

Abouzeedan, A. (2003). Financing Swedish Small and Medium-Sized Enterprises (SMEs): Methods, Problems and Impact. Paper presented at the 43rd European Congress of the Regional Science Association, Jyväskylä, Finland.

Albaum, G. (1983). Effectiveness of Government Export Assistance for U.S. Smaller-Sized Manufacturers: Some Further Evidence. International Marketing Review, 1(1), 68-75. http://dx.doi.org/10.1108/eb008246

Al-Harran, S. A. S. (1993). Islamic Finance: Partnership Financing. Pelanduk Publications.

Allen, F., Qian, M., \& Qian, J. (2005). Law, Finance, and Economic Growth in China. Journal of Financial Economics, 77(1), 57-116. http://dx.doi.org/10.1016/j.jfineco.2004.06.010

Arena, M. P. (2011). The Corporate Choice Between Public Debt, Bank Loans, Traditional Private Debt Placements, and 144A Debt Issues. Review of Quantitative Finance and Accounting, 36(3), 391-416. http://dx.doi.org/10.1007/s11156-010-0182-3

Aryeetey, E. (1998). Informal Finance for Private Sector Development in Africa. African Development Bank Group.

Atieno, R. (2001). Formal and Informal Institutions' Lending Policies and Access to Credit by Small-Scale Enterprises in Kenya: An Empirical Assessment. Nairobi, Kenya: African Economic Research Consortium.

Ayyagari, M., Demirgüç-Kunt, A., \& Maksimovic, V. (2010). Formal versus Informal finance: Evidence from China. Review of Financial Studies, 23(8), 3048-3097. http://dx.doi.org/10.1093/Rfs/Hhq030

Badulescu, A. (2011). Start-Up Financing Sources: Does Gender Matter? Some Evidence for EU and Romania. Annals of the University of Oradea: Economic Science, Romania, 1, 207-213.

Barry, C. B. (1994). New Directions in Research on Venture Capital Finance. Financial Management, 23(3), 3-15. http://dx.doi.org/10.2307/3665617

Barton, S. L., \& Gordon, P. J. (1987). Corporate Strategy: Useful Perspective for the Study of Capital Structure? The Academy of Management Review, 12(1), 67.

Bascha, A., \& Walz, U. (2001). Convertible Securities and Optimal Exit Decisions in Venture Capital Finance. Journal of Corporate Finance, 7(3), 285-306. http://dx.doi.org/10.1016/S0929-1199(01)00023-2

Bechri, M., Najah, T., \& Nugent, J. B. (2001). Tunisia's Lending Program to SMEs: Anatomy of an Institutional Failure? Small Business Economics, 17(4), 293-308. http://dx.doi.org/10.1023/A:1012282023692

Beck, T., Demirgüç-Kunt, A., \& Martinez Peria, M. S. (2008). Bank Financing for SMEs Around the World: Drivers, Obstacles, Business Models, and Lending Practices. The World Bank. http://dx.doi.org/10.1596/1813-9450-4785

Bergemann, D., \& Hege, U. (1998). Venture Capital Financing, Moral Hazard, and Learning. Journal of Banking and Finance, 22(6), 703-735. http://dx.doi.org/10.1016/S0378-4266(98)00017-X

Berger, A. N., \& Frame, W. S. (2007). Small Business Credit Scoring and Credit Availability. Journal of Small 
Business Management, 45(1), 5-22. http://dx.doi.org/10.1111/j.1540-627X.2007.00195.x

Berger, A. N., \& Udell, G. F. (1998). The Economics of Small Business Finance: The Roles of Private Equity and Debt Markets in the Financial Growth Cycle. Journal of Banking and Finance, 22, 613-673. http://dx.doi.org/10.1016/S0378-4266(98)00038-7

Berger, A. N., \& Udell, G. F. (2006). A More Complete Conceptual Framework for SME Finance. Journal of Banking and Finance, 30(11), 2945-2966. http://dx.doi.org/10.1016/j.jbankfin.2006.05.008

Berger, A. N., Frame, W. S., \& Miller, N. H. (2002). Credit Scoring and the Availability, Price, and Risk of Small Business Credit. Journal of Money, Credit and Banking, 37(2), 191-222. http://dx.doi.org/10.1353/mcb.2005.0019

Berggren, B., Olofsson, C., \& Silver, L. (2000). Control Aversion and the Search for External Financing in Swedish SMEs. Small Business Economics, 15(3), 233-242. http://dx.doi.org/10.1023/A:1008153428618

Boocock, J., \& Shariff, M. (2005). Measuring the Effectiveness of Credit Guarantee Schemes: Evidence from $\begin{array}{lllll}\text { Malaysia. International Small Business } & \text { Journal, }\end{array}$ http://dx.doi.org/10.1177/0266242605054054

Bradley, M., Jarrell, G. A., \& Kim, E. H. (1984). On the Existence of an Optimal Capital Structure: Theory and Evidence. The Journal of Finance, 39(3), 857-878. http://dx.doi.org/10.1111/j.1540-6261.1984.tb03680.x

Brettel, M. (2003). Business Angels in Germany: A Research Note. Venture Capital, 5(3), 251-268. http://dx.doi.org/10.1080/1369106032000122095

Briozzo, A., \& Vigier, H. (2009). A Demand-Side Approach to SMEs' Capital Structure: Evidence from Argentina. Journal of Business and Entrepreneurship, 21(1), 30.

Bygrave, W. D., \& Timmons, J. A. (1992). Venture Capital at the Crossroads. Harvard Business Press.

Carey, D., \& Flynn, A. (2005). Is Bank Finance the Achilles' Heel of Irish SMEs? Journal of European Industrial Training, 29(8/9), 712. http://dx.doi.org/10.1108/03090590510629849

Carter, S., \& Rosa, P. (1998). The Financing of Male and Female Owned Businesses. Entrepreneurship and Regional Development, 10(3), 225-242. http://dx.doi.org/10.1080/08985629800000013

Cassar, G. (2004). The Financing of Business Start-Ups. Journal of Business Venturing, 19(2), 261-283. http://dx.doi.org /10.1016/S0883-9026(03)00029-6

Cassar, G., \& Holmes, S. (2003). Capital Structure and Financing of SMEs: Australian Evidence. Accounting and Finance, 43(2), 123-147. http://dx.doi.org/10.1111/1467-629X.t01-1-00085

Chittenden, F., Hall, G. C., \& Hutchinson, P. J. (1996). Small Firm Growth, Access to Capital Markets and Financial Structure: Review of Issues and an Empirical Investigation. Small Business Economics, 8(1), 59-67. http://dx.doi.org /10.1007/Bf00391976

Coco, G. (2000). On the Use of Collateral. Journal of Economic Surveys, 14(2), 191-214. http://dx.doi.org/10.1111/1467-6419.00109

Cole, R. A. (1998). The Importance of Relationships to the Availability of Credit. Journal of Banking and Finance, 22(6), 959-977. http://dx.doi.org /10.1016/S0378-4266(98)00007-7

Cole, R. A., \& Wolken, J. D. (1995). Financial Services Used by Small Businesses: Evidence from the 1993 National Survey of Small Business Finances. Federal Reserve Bulletin, 81(7), 629.

Coleman, S. (2007). The Role of Human and Financial Capital in the Profitability and Growth of Women-Owned Small Firms. Journal of Small Business Management, 45(3), 303-319. http://dx.doi.org/10.1111/j.1540-627X.2007.00214.x

Coleman, S., \& Cohn, R. (2000). Small Firms' Use of Financial Leverage: Evidence from the 1993 National Survey of Small Business Finances. Journal of Business and Entrepreneurship, 12(3), 81.

Cook, L. (1999). Trade Credit and Bank Finance: Financing Small Firms in Russia. Journal of Business Venturing, 14(5-6), 493-518. http://dx.doi.org/10.1016/S0883-9026(98)00026-3

Cook, P. (2001). Finance and Small and Medium-Sized Enterprise in Developing Countries. Journal of Developmental Entrepreneurship, 6(1), 17.

Cumming, D. (2006). Adverse Selection and Capital Structure: Evidence from Venture Capital. Entrepreneurship Theory and Practice, 30(2), 155-183. http://dx.doi.org/10.1111/j.1540-6520.2006.00116.x 
Cziráky, D., Tišma, S., \& Pisarović, A. (2005). Determinants of the Low SME Loan Approval Rate in Croatia. Small Business Economics, 25(4), 347-372. http://dx.doi.org/10.1007/s11187-004-6481-0

De Bettignies, J., \& Brander, J. A. (2007). Financing Entrepreneurship: Bank Finance Versus Venture Capital. Journal of Business Venturing, 22(6), 808-832. http://dx.doi.org/10.1016/j.jbusvent.2006.07.005

De la Torre, A., Martinez Peria, M., \& Schmukler, S. (2009). Drivers and Obstacles to Banking SMEs: The Role of Competition and the Institutional Framework. The World Bank.

Demirgüç-Kunt, A., \& Maksimovic, V. (2001). Firms as Financial Intermediaries: Evidence from Trade Credit Data. The World Bank.

Denis, D. J., \& Mihov, V. T. (2003). The Choice Among Bank Debt, Non-Bank Private Debt, and Public Debt: Evidence from New Corporate Borrowings. Journal of Financial Economics, 70(1), 3-28. http://dx.doi.org/10.1016/S0304-405x(03)00140-5

Dhumale, R., \& Sapcanin, A. (1999). An Application of Islamic Banking Principles to Microfinance. A study by the Regional Bureau for Arab States, UNDP, in cooperation with the Middle East and North Africa Region Group, The World Bank.

Elliehausen, G. E., \& Wolken, J. D. (1993). The Demand for Trade Credit: An Investigation of Motives for Trade Credit Use by Small Businesses. Federal Reserve Bulletin, 79(10), 929.

Fairchild, R. (2011). An Entrepreneur's Choice of Venture Capitalist or Angel Financing: A Behavioral Game-Theoretic Approach. Journal of Business Venturing, 26(3), 359-374. http://dx.doi.org/10.1016/j.jbusvent.2009.09.003

Fatoki, O., \& Asah, F. (2011). The Impact of Firm and Entrepreneurial Characteristics on Access to Debt Finance by SMEs in King Williams' Town, South Africa. International Journal of Business and Management, 6(8), 170-179. http://dx.doi.org/10.5539/ijbm.v6n8p170

Fatoki, O., \& Odeyemi, A. (2010). The Determinants of Access to Trade Credit by New SMEs in South Africa. African Journal of Business Management, 4(13), 2763-2770.

Frame, W. S., Srinivasan, A., \& Woosley, L. (2001). The Effect of Credit Scoring on Small Business Lending. Journal of Money, Credit and Banking, 33(3), 813-825. http://dx.doi.org/10.2307/2673896

Gafoor, A. L. M. A. (2006). Mudaraba-Based Investment and Finance. Journal of Islamic Banking and Finance, 23(4), 78-98.

Gait, A., \& Worthington, A. C. (2007). A Primer on Islamic Finance: Definitions, Sources, Principles and Methods. University of Wollongong, School of Accounting and Finance Working Paper Series, No. 07/05, 2007.

García-Teruel, P. J., \& Martínez-Solano, P. (2007). Short-Term Debt in Spanish SMEs. International Small Business Journal, 25(6), 579-602. http://dx.doi.org/10.1177/0266242607082523

García-Teruel, P. J., \& Martínez-Solano, P. (2010). Determinants of Trade credit: A Comparative Study of European SMEs. International Small Business Journal, 28(3), 215-233. http://dx.doi.org/10.1177/0266242609360603

Goff, S., \& Nasiripour, S. (2012). Non-Bank Lending on Rise for UK SMEs. Financial Times, 9, April 2012.

Gompers, P. A. (1995). Optimal Investment, Monitoring, and the Staging of Venture Capital. The Journal of Finance, 50(5), 1461-1489. http://dx.doi.org/10.2307/2329323

Gompers, P., Kovner, A., Lerner, J., \& Scharfstein, D. (2010). Performance persistence in entrepreneurship. Journal of Financial Economics, 96(1), 18-32. http://dx.doi.org/10.1016/j.jfineco.2009.11.001

Gorman, M., \& Sahlman, W. A. (1989). What Do Venture Capitalists Do? Journal of Business Venturing, 4(4), 231-248. http://dx.doi.org/10.1016/0883-9026(89)90014-1

Green, R. C. (1984). Investment Incentives, Debt, and Warrants. Journal of Financial Economics, 13(1), 115-136. http://dx.doi.org/10.1016/0304-405x(84)90034-5

Gregory, B. T., Rutherford, M. W., Oswald, S., \& Gardiner, L. (2005). An Empirical Investigation of the Growth Cycle Theory of Small Firm Financing. Journal of Small Business Management, 43(4), 382-392. http://dx.doi.org/10.1111/j.1540-627X.2005.00143.x

Harding, R., \& Cowling, M. (2006). Points of View: Assessing the Scale of the Equity Gap. Journal of Small 
Business and Enterprise Development, 13(1), 115-132. http://dx.doi.org/10.1108/14626000610645351

Harrison, R. T., \& Mason, C. M. (1992). International Perspectives on the Supply of Informal Venture Capital. Journal of Business Venturing, 7(6), 459-475. http://dx.doi.org/10.1016/0883-9026(92)90020-R

Harrison, R. T., \& Mason, C. M. (2007). Does Gender Matter? Women Business Angels and the Supply of Entrepreneurial Finance. Entrepreneurship Theory and Practice, 31(3), 445-472. http://dx.doi.org/10.1111/j.1540-6520.2007.00182.x

He, W., \& Baker, H. K. (2007). Small Business Financing: Survey Evidence in West Texas. The Journal of Entrepreneurial Finance and Business Ventures, 12(1), 27.

Hellmann, T. (1998). The Allocation of Control Rights in Venture Capital Contracts. The RAND Journal of Economics, 29(1), 57-76. http://dx.doi.org/10.2307/2555816

Helwege, J., \& Liang, N. (1996). Is There a Pecking Order? Evidence from a Panel of IPO Firms. Journal of Financial Economics, 40(3), 429-458. http://dx.doi.org/10.1016/0304-405X(95)00851-5

Hernández-Cánovas, G., \& Martínez-Solano, P. (2010). Relationship Lending and SME Financing in the Continental European Bank-Based System. Small Business Economics, 34(4), 465-482. http://dx.doi.org/10.1007/s11187-008-9129-7

Hutchinson, P. (1999). Small Enterprise: Finance, Ownership and Control. International Journal of Management Reviews, 1(3), 343-365. http://dx.doi.org/10.1111/1468-2370.00018

Hutchinson, R. W. (1995). The Capital Structure and Investment Decision of the Small Owner-Managed Firm: Some Exploratory Issues. Small Business Economics, 7(3), 231-239. http://dx.doi.org/10.1007/BF01135368

Huyghebaert, N., \& Van de Gucht, L. M. (2007). The Determinants of Financial Structure: New Insights from Business Start-Ups. European Financial Management, 13(1), 101-133. http://dx.doi.org/10.1111/j.1468-036X.2006.00287.x

Ibrahim, B. A. (2003). Poverty Alleviation via Islamic Banking Finance to Micro-Enterprises in Sudan: Some Lessons for Poor Countries. Institute for World Economics and International Management (IWIM), Sudan Economy Research Group, Discussion Paper, University of Bremen.

Irwin, D., \& Scott, J. M. (2010). Barriers Faced by SMEs in Raising Bank Finance. International Journal of Entrepreneurial Behaviour and Research, 16(3), 245-259. http://dx.doi.org/10.1108/13552551011042816

Johnson, S. A. (1997). An Empirical Analysis of the Determinants of Corporate Debt Ownership Structure. Journal of Financial and Quantitative Analysis, 32(1), 47-69. http://dx.doi.org/10.2307/2331316

Jun, S., \& Jen, F. C. (2003). Trade-off Model of Debt Maturity Structure. Review of Quantitative Finance and Accounting, 20(1), 5-34. http://dx.doi.org/10.1023/A:1022190205033

Keasey, K., \& McGuinness, P. (1990). Small New Firms and the Return to Alternative Sources of Finance. Small Business Economics, 2(3), 213-222. http://dx.doi.org/10.1007/BF00389529

Khan, T., \& Ahmed, H. (2001). Risk Management: An analysis of Issues in Islamic Financial Industry. Islamic Development Bank and Islamic Research and Training Institute.

Kimhi, A. (1997). Intergenerational Succession in Small Family Businesses: Borrowing Constraints and Optimal Timing of Succession. Small Business Economics, 9(4), 309-318. http://dx.doi.org/10.1023/A:1007987731337

Klapper, L., Sarria-Allende, V., \& Sulla, V. (2002). Small and Medium-Size Enterprise Financing in Eastern Europe. World Bank Publications. http://dx.doi.org/10.1596/1813-9450-2933

Klyuev, V. (2008). Show Me the Money: Access to Finance For Small Borrowers in Canada (Vol. 8). International Monetary Fund.

Kortum, S., \& Lerner, J. (2000). Assessing the Contribution of Venture Capital to Innovation. The RAND Journal of Economics, 31(4), 674-692. http://dx.doi.org/10.2307/2696354

La Rocca, M., La Rocca, T., \& Cariola, A. (2011). Capital Structure Decisions During a Firm's Life Cycle. Small Business Economics, 37(1), 107-130. http://dx.doi.org/10.1007/s11187-009-9229-z

Landström, H. (1993). Informal Risk Capital in Sweden and Some International Comparisons. Journal of Business Venturing, 8(6), 525-540. http://dx.doi.org/10.1016/0883-9026(93)90037-6

Lerner, J. (1994). The Syndication of Venture Capital Investments. Financial Management, 23(3), 16-27. 
http://dx.doi.org/10.2307/3665618

Lewis, M., \& Algaoud, L. M. (2001). Islamic Banking. Edward Elgar Cheltenham.

MacKay, P., \& Phillips, G. M. (2005). How Does Industry Affect Firm Financial Structure? The Review of Financial Studies, 18(4), 1433-1466. http://dx.doi.org/10.1093/rfs/hhi032

Madill, J., Haines, G., \& Riding, A. (2005). The Role of Angels in Technology SMEs: A Link to Venture Capital. Venture Capital - An International Journal of Entrepreneurial Finance, 7(2), 107-129. http://dx.doi.org/10.1080/1369106042000316341

Mason, C. M., \& Harrison, R. T. (1996). Informal Venture Capital: A Study of the Investment Process, the Post-Investment Experience and Investment Performance. Entrepreneurship and Regional Development, 8(2), 105-126. http://dx.doi.org/10.1080/08985629600000007

Mensah, S. (2004). A Review of SME Financing Schemes in Ghana. Paper presented at the UNIDO Regional Workshop of Financing Small and Medium Scale Enterprises, Accra, Ghana.

Mian, S. L., \& Smith, C. W. (1992). Accounts Receivable Management Policy: Theory and Evidence. The Journal of Finance, 47(1), 169-200. http://dx.doi.org/10.2307/2329094

Michaelas, N., Chittenden, F., \& Poutziouris, P. (1999). Financial Policy and Capital Structure Choice in U.K. SMEs: Empirical Evidence from Company Panel Data. Small Business Economics, 12(2), 113-130. http://dx.doi.org/10.1023/A:1008010724051

Mijid, N. (2009). Gender, Race, and Credit Rationing of Small Businesses: Empirical Evidence from the 2003 Survey of Small Business Finances. PhD thesis, Colorado State University.

Moro, A., Lucas, M., Grimm, U., \& Grassi, E. (2010). Financing SMEs: A Model for Optimising the Capital Structure. Paper presented at the 17th Annual Global Finance Conference, Poznan, Poland.

Morrissette, S. G. (2007). A Profile of Angel Investors. The Journal of Private Equity, 10(3), 52-66. http://dx.doi.org/10.3905/jpe.2007.686430

Myers, S. C. (1977). Determinants of Corporate Borrowing. Journal of Financial Economics, 5(2), 147-175. http://dx.doi.org/10.1016/0304-405x(77)90015-0

Myers, S. C. (1984). The Capital Structure Puzzle. The Journal of Finance, 39(3), 574-592. http://dx.doi.org/10.2307/2327916

Nofsinger, J. R., \& Wang, W. (2011). Determinants of Start-Up Firm External Financing Worldwide. Journal of Banking and Finance, 35(9), 2282-2294. http://dx.doi.org/10.1016/j.jbankfin.2011.01.024

Obaidullah, M., \& Latiff, H. S. H. A. (2008). Islamic Finance for Micro and Medium Enterprises. Islamic Research and Training Institute, Islamic Development Bank and Centre for Islamic Banking, Finance and Management, University of Brunei Darussalam.

Odit, M. P., \& Gobardhun, Y. D. (2011). The Determinants of Financial Leverage of SME's in Mauritius. The International Business and Economics Research Journal, 10(3), 113.

OECD. (2000). Small and Medium Enterprise Outlook: 2000 Edition. Paris: OECD Publications. http://dx.doi.org/10.1787/sme_outlook-2000-en

OECD. (2004). Promoting Entrepreneurship and Innovative SMEs in a Global Economy. Paper presented at the 2nd OECD conference of ministers responsible for small and medium-sized enterprises (SMEs), Istanbul, Turkey.

Okpara, J. O., \& Wynn, P. (2007). Determinants of Small Business Growth Constraints in a Sub-Saharan African Economy. Advanced Management Journal, 72(2), 24.

Ono, A., \& Uesugi, I. (2009). Role of Collateral and Personal Guarantees in Relationship Lending: Evidence from Japan's SME Loan Market. Journal of Money, Credit and Banking, 41(5), 935-960. http://dx.doi.org/10.1111/j.1538-4616.2009.00239.x

Ou, C., \& Haynes, G. W. (2006). Acquisition of Additional Equity Capital by Small Firms - Findings from the National Survey of Small Business Finances. Small Business Economics, 27(2), 157-168. http://dx.doi.org/10.1007/s11187-006-0009-8

Petersen, M. A., \& Rajan, R. G. (1994). The Benefits of Lending Relationships: Evidence from Small Business Data. Journal of finance, 49(1), 3-37. http://dx.doi.org/10.2307/2329133 
Petty, J., \& Bygrave, W. (1993). What Does Finance Have to Say to the Entrepreneur. The Journal of Small Business Finance, 2(2), 125-137.

Potter, J., \& Porto, A. (2007). Promoting Entrepreneurship in South East Europe: Policies and Tools. OECD Papers, 6(12), 1. http://dx.doi.org/10.1787/oecd_papers-v6-art39-en

Quartey, P. (2003). Financing Small and Medium Enterprises (SMEs) in Ghana. Journal of African Business, 4(1), 37-55. http://dx.doi.org/10.1300/J156v04n01_03

Reddy, M. (2007). Small Business in Small Economies: Constraints and Opportunities for Growth. Social and economic studies, 56(1/2), 304-321.

Reid, G. C. (1996). Mature Micro-Firms and Their Experience of Funding Shortages. Small Business Economics, 8(1), 27-37. http://dx.doi.org/10.1007/Bf00391973

Riding, A., Madill, J., \& Haines, G. (2007). Incrementality of SME Loan Guarantees. Small Business Economics, 29(1), 47-61. http://dx.doi.org/10.1007/s11187-005-4411-4

Romano, C. A., Tanewski, G. A., \& Smyrnios, K. X. (2001). Capital Structure Decision Making: A Model for Family Business. Journal of Business Venturing, 16(3), 285-310. http://dx.doi.org/10.1016/S0883-9026(99)00053-1

Sánchez-Vidal, J., \& Martín-Ugedo, J. F. (2005). Financing Preferences of Spanish Firms: Evidence on the Pecking Order Theory. Review of Quantitative Finance and Accounting, 25(4), 341-355. http://dx.doi.org/10.1007/s11156-005-5459-6

Satta, T. A. (2006). Performance Evaluation of Three Small Firms' Financing Fchemes in Tanzania. Journal of Accounting and Organizational Change, 2(2), 164-164. http://dx.doi.org/10.1108/18325910610675998

Schäfer, D., Werwatz, A., \& Zimmermann, V. (2004). The Determinants of Debt and Private Equity Financing: The Case of Young, Innovative SMEs from Germany. Industry and Innovation, 11(3), 225-248. http://dx.doi.org/10.1080/1366271042000265393

Segrado, C. (2005). Islamic Microfinance and Socially Responsible Investments, Case study. University of Turin.

Shane, S. (2012). The Importance of Angel Investing in Financing the Growth of Entrepreneurial Ventures. The Quarterly Journal of Finance, 2(2). http://dx.doi.org/10.1142/S2010139212500097

Smolarski, J., \& Kut, C. (2011). The Impact of Venture Capital Financing Method on SME Performance and Internationalization. International Entrepreneurship and Management Journal, 7(1), 39-55. http://dx.doi.org/10.1007/s11365-009-0128-1

Soufani, K. (2002). On the Determinants of Factoring as a Financing Choice: Evidence from the UK. Journal of Economics and Business, 54(2), 239-252. http://dx.doi.org/10.1016/S0148-6195(01)00064-9

Stedler, H., \& Peters, H. H. (2003). Business Angels in Germany: An Empirical Study. Venture Capital, 5(3), 269-276. http://dx.doi.org/10.1080/1369106032000126596

Stein, J. C. (1992). Convertible Bonds as Backdoor Equity Financing. Journal of Financial Economics, 32(1), 3-21. http://dx.doi.org/10.1016/0304-405x(92)90022-P

Storey, D. J. (1994). Understanding the Small Business Sector. Thomson Learning Emea.

Van Auken, H. E., \& Neeley, 1. (1996). Evidence of Bootstrap Financing Among Small Start-Up Firms. Journal of Entrepreneurial and Small Business Finance, 5(3), 235.

Van der wijst, D. (1989). Financial Structure in Small Business: Theory, Tests and Applications (Vol. 320). Berlin: Springer. http://dx.doi.org/10.1007/978-3-642-45656-5

Vera, D., \& Onji, K. (2010). Changes in the Banking System and Small Business Lending. Small Business Economics, 34(3), 293-308. http://dx.doi.org/10.1007/s11187-008-9119-9

Verheul, I., \& Thurik, R. (2001). Start-Up Capital: Does Gender Matter? Small Business Economics, 16(4), 329-346. http://dx.doi.org/10.1023/A:1011178629240

Vos, E., Yeh, A. J., Carter, S., \& Tagg, S. (2007). The Happy Story of Small Business Financing. Journal of Banking and Finance, 31(9), 2648-2672. http://dx.doi.org/10.1016/j.jbankfin.2006.09.011

Wall, L. D. (2007). On Investing in the Equity of Small Firms. Journal of Small Business Management, 45(1), 89-93. http://dx.doi.org/10.1111/j.1540-627X.2007.00200.x

Wang, S., \& Zhou, H. (2004). Staged Financing in Venture Capital: Moral Hazard and Risks. Journal of 
Corporate Finance, 10(1), 131-155. http://dx.doi.org/10.1016/S0929-1199(02)00045-7

Warde, I. (2000). The Revitalization of Islamic Profit-and-loss Sharing. Paper presented at the Harvard University Forum on Islamic Finance.

Wilson, N., \& Summers, B. (2002). Trade Credit Terms Offered by Small Firms: Survey Evidence and Empirical Analysis. Journal of Business Finance and Accounting, 29(3-4), 317-351. http://dx.doi.org/10.1111/1468-5957.00434

Wright, M., \& Lockett, A. (2003). The Structure and Management of Alliances: Syndication in the Venture Capital Industry. Journal of Management Studies, 40(8), 2073-2102. http://dx.doi.org/10.1046/j.1467-6486.2003.00412.x

Wu, J., Song, J., \& Zeng, C. (2008). An Empirical Evidence of Small Business Financing in China. Management Research News, 31(12), 959-975. http://dx.doi.org/10.1108/01409170810920666

Yano, G., \& Shiraishi, M. (2012). Efficiency of Trade Credit Finance in China. Comparative Economic Studies, 54(1), 203-225. http://dx.doi.org/10.1057/ces.2011.30

Zecchini, S., \& Ventura, M. (2009). The Impact of Public Guarantees on Credit to SMEs. Small Business Economics, 32(2), 191-206. http://dx.doi.org/10.1007/s11187-007-9077-7

Zhou, W. (2009). Bank Financing in China's Private Sector: The Payoffs of Political Capital. World Development, 37(4), 787-799. http://dx.doi.org/10.1016/j.worlddev.2008.07.011

\section{Copyrights}

Copyright for this article is retained by the author(s), with first publication rights granted to the journal.

This is an open-access article distributed under the terms and conditions of the Creative Commons Attribution license (http://creativecommons.org/licenses/by/3.0/). 